\author{
KALISHCHUK OKSANA, \\ Lesya Ukrainka Eastern European National University (Lutsk, Ukraine) \\ e-mail:kalis@ukr.net, ORCID0000-0003-1272-7920
}

\title{
VOLYN TRAGEDY IN CINEMA AND THEATRE
}

Cinema is rightly considered as a powerful socio-communicative channel of information space. Its significance is strengthened in a case of appealing to the ticklish topic. An overview of works of cinema and theater art devoted to the Ukrainian-Polish conflict in the years of World War II on the West of Ukraine are proposed in article. The attention is paid not only to the plot variety of the films, but also to the philosophical, hermeneutical, psychoanalytic opportunities and the requirement of their thorough study. Thus, an accent on the individualization of the Volhynian events through the person of witnesses, people who survived it, has become specific in particular to the chronicle-documentary and popular science-fiction films. The feature of documentary films about Volyn' 43 is the inability to make them more aesthetic and distant. The ability to cause emotional empathy should be considered the main task of both cinematography and theater at the present stage. Today, cinema and theatre works are the elements of national self-identification and the formation of national memory. Documentary and especially feature films can restore and reinforce old stereotypes and create new myths. The more than seventy-years-old experience is becoming an experience of contemporaries through the means of modern art. It is concluded that both documentary and featured films and theatrical performances are one of the ways of international dialogue. Intensive discussions that are prompted in Ukrainian and Polish societies by such feature films as "Volyn" by Wojciech Smarzowski are the bright demonstration of its oversignificance. At the same time, it should be understood that it is important to talk about topics that are painful to the society.

Keywords: Volyn tragedy; theatre; documentary film; feature film.

\section{Introduction}

Nowadays it is common knowledge that there is nothing like mass culture to help people with telling their stories, nothing like mass culture to effect on national historical memory. The spreading of cinema, the extension of its influence in different levels of social consciousness, in opinion of Ukrainian researcher Sergey Marchenko, bears a remote resemble of another phenomenon that was developing synchronically, the discovery of atom bomb: "Atomic scientist were searching for fundamentally new cheap energy, cineastes - means of influencing on the spectator..." (Marchenko, 2002).

The Ukrainian-Polish conflict at the time of World War II is the topic for active researches of Ukrainian, Polish, West European and American scientists. Today the basic areas within the boundaries of national historiographies (revisionists, traditionalists, extrascientists) are defined with specific variability, head researchers of problems are well-known. So, Tadeusz A. Olszański (Łukaszów, 1989), Andrzej L. Sowa (Sowa, 1998), Ryszard Torzecki (Torzecki, 1993) etc. can be named here. Among Polish historians we should mark out Grzegorz Motyka, the evolution of whose sights demonstrates predomination of radical course over liberal in modern Polish historical sciences (Motyka, 2016). Meaningful progress of Ukrainian scientists is demonstrated in studies of Bogdan Hud (2018), Volodymyr Vyatrovich (2011), Igor llyushyn (2001), Oksana Kalishchuk (2016) and others. However, complex analysis of reflection of the Volhynian events in cinema and theatrical art, which is actual due to qualitative and quantitative changes in this sphere and their effect on the society, was neglected by specialists.

The purpose of the research is an analysis of the delicate topic of the Ukrainian-Polish conflict in modern cinema and theatre. The task of the article is also to determine effects of cine and theatre products on the social discourse; to characterize the image of the Volhynian events in documentary and feature films; to highlight the evolution of cineastes' tasks of from informative tasks to the work with spectator's emotions.

\section{Methods}

Complex of research methods used in the article consists of general scientific methods (analysis, synthesis, periodization, terminologization, classification), interdisciplinary methods (method of psychological analysis) and socio-historical methods. Among other, there were used comparative method, problem-chronological, system, genetic, typological method. The analysis of reflection of Volyn tragedy in cinema and theatre required the use of interdisciplinary approach which allowed to reveal multidimensionality of the problem.

\section{Results}

In the case of experience of work with the difficult past the example of the Holocaust is considered to be most notable. Shoah is generally known through the mass culture. Jews should be commended here - they made hundreds of cine products for different audience. Among 
them, there are documentary films that help with investigating the facts; arthouse that allows directors to reinterpret this event again and again; mass and popular films famous actors directed by remarkable directors. In response to "The Pianist" by Roman Polanski, "Schindler's List" Steven Spielberg, "Sophie's Choice" by Alan J. Pakula our contemporary not only knows, but also feels what happened to Jews in the years of World War II. Alison Lansberg, among other things, wrote about phenomena of history identification with its presentation in cinema as "prosthetic memory" (Landsberg, 2004: 2).

There is every reason to suppose that today people try to insert the topic of Volynia'43 in the overall tendency of genocide studies and Holocaust Industry, to use of similar approaches of popularization of knowledge about happenings of the Ukrainian-Polish conflict in the years of World War II in Volynia, Eastern Galicia, Chełm Land and Podlachia. In particular, there is valid position of Ivan Patryliak, who states that in modern democratic Poland the plan for construction of classic "holocaust industry", which is destined to become one of foundation stones of Polish collective memory, is implemented (Patryliak, 2014: 149). It is important that the history of long past in such forms as documentary films is given to the younger generation and just at the time when young people' consciousness and the ability of analyzing is in process of forming.

The mastership of documentary lies in ability to get the spectator interested. First documentary films dedicated to the "Volhynian events" appeared in Poland as recently as the nineties of the twentieth century. In this time films "Wołyń 1943 - Kryptonim "Pożoga", directed by Wincenty Ronicz, "Wołyń 1943 - Bliscy a dalecy", directed by Anna Górna, Lubomie Zając, Michał Tkaczuk appear. New explosion of interest was related to the sixtieth anniversary in 2003 ("Wołyń - zapis zbrodni", scenarist Jadwiga Nowakowska; "Było sobie miasteczko", directed by Tadeusz Arciuch, Maciej Wojciechowski) and seventieth anniversary in 2013 ("Szlakiem Wołyńskich Krzyży", directed by Marek Chapla, "Ukraiński rapsod", directed by Dariusz Marek Srzednicki, "Zapomniane zbrodnie na Wołyniu", directed by Tadeusz Arciuch). Also there should be mentioned such films from Ukrainian side as "Volhynia - 1943" by Ihor Chizhov ("Inter"), "Volhynia. Sign of trouble" by Alexandr Balaban and Alexander Radinsky ("First National"), "Volyn tragedy: sight from Ukraine" by Halyna Tereshuk. Among late works there should be named documental-publicistic four-episode "Memory Syndrome" (scriptwriters - Maxim Shapka and Olena Vavilova), "Volyn Tragedy. Memory. Sorrow. Reconciliation" (author - Maria Andrushenko, Volhynian television), "Лукаве Ludobójstwo" (scriptwriter and director - Andriy Smus).

Documentary films had not always elicited unambiguous reaction of spectators. After exhibition of the work of Agnieszka Arnold ("Purification", the first part which showed Ukrainian viewpoint on Volhynian events, at first and then "Forgiveness", the second part which presented Polish position) Ethic committee of media at the instigation of "kresovyatski" surroundings accused the author of disregard of journalism norms and only the court of law put the things right.

Worthy of special mention is film by BBC journalist Wanda Koscia "My Friend the Enemy" (pol. Mój przyjaciel wróg), based on eye witnesses' account, that tend to show positive experience in such touchy topic not through the mutual accusations, but paying attention to examples of rescue Polish neighbors by Ukrainian people. This film provoked noticeable comments and was admitted particularly interesting film, which gives much food for reflection, by famous English historian Norman Davies (Mój przyjaciel wróg... URL). At another point, writer and journalist Neal Ascherson named it the part of mosaic which has been missing: "It is not only about what Ukrainian and Polish people did to each other, but also about all horrible events of war. This film represents more incomprehensible cruelty and moral confusion than numerous films and books about the Holocaust or massacres in French Oradoursur-Glane, or about Warsaw. Neighbors, who can go against neighbors firstly, and then risk their lives for saving strangers in Jesus Christ' name..." (Mój przyjaciel wróg... $U R L)$. Not coincidentally, in opinion of John-Paul Himka, paying attention to survived people demonstrates the historical memory softly, though mightily; sparks of such humanity make possible wading through that dark times (Mój przyjaciel wróg... URL).

In terms of consideration documentary of films dedicated to Volynia'43, the related telepublicism genre should be examined. So, special issue on this topic were prepared by leading historical "Historical truth with Vakhtang Kipiani" and "Unclassified history" (the presenter - Oleksandr Zinchenko) and socio-political ("Opposite sight", "Ideologic choice" etc.) programmes. Even more the Ukrainian-Polish conflict in the years of World War II is present at Polish television ("Niedokonczone rozmowy", "Wideoczat $z$ historia" etc.). This is an additional demonstration of the relevance of the topic and the role of documentary in forming public opinion.

In general, over the past quarter of the century, many documentary films dedicated to Volyn'43 were screened. They were different in their artistic value, form, way of disclosing the topic, the position of the author, target audience etc. The text that accompanies the image in a documentary film (sometimes, on the other hand, the image accompanies the text) performs informational, propagandist and aesthetic functions. It is also important to note that over the last years, the syncs with witnesses are losing their auxiliary appointment regarding to the author's text and they become the main source of emotional information and content. While the first films, as qualitative publicism and rather historical journalism, performed primarily informational and educational functions, now, when much has been written and said about Volyn'43, more important is not what is said, but how it is said. With increasing frequency we can find examples of deep artistic reflections on the traumas of the past and the challenges of modernity (another question is how strongly we agree with them).

The demonstration of the importance of documentary films for forming the memory about Volhynian events is organizing the special viewings on this topic by the Institute of National Remembrance. Thus, within the framework of the 70th anniversary during one of such viewings in Lodz, four films were offered ("Skrawekpiekław Podolu", "Zapomniane zbrodniena Wołyniu", "Było sobie miasteczko", "Woł yń wpożodze").

A special, if not an exceptional place among the artistic cinematographic works belongs to the "Volyn", the first and, so far, the only feature film dedicated to Volyn tragedy, which sparked a wide response even before the release (Kalishchuk, 2016: 53-54). In his interviews the director Wojciech Smarzowski declared his desire to make a film that would become a bridge, not a wall between peoples, to initiate a dialogue between Ukrainians and Poles concerning the Volhynian events. It was rather wishful thinking, because neither the text that the script had been based on ("Hate" by Stanisław Srokowski), nor the artist's intention to make a picture with the Polish perspective, that, after all, he did not hide from the very beginning, did not allow to talk about 
the discovering the truth. The symbolism of "Volyn" begins from the first frames - from the motto (epigraph) "Kresovians were killed twice: the first time they were struck by an axe, and the second time they were killed through the suppression. The second death is worse than the first", which belongs to Jan Zaleski, the father of the notorious priest Tadeusz Isakowicz-Zaleski. The film is started with the scene of the wedding which is also symbolic - in this scene we can see the marriage of Ukrainian man and Pole woman.

Many episodes are not fiction and correspond to the historical truth. So, for example, it is easy to read events in the Kisilin Church, known from the descriptions of Włodzimierz Sławomir Dębski. A quite impressive scene of breaking the negotiator with horses for historians is connected with the fate of the famous poet Zygmunt Jan Rumel, which the mention to his poem "Two homelands" refers to. The director did not spare so called "retaliation actions", which caused ambiguous reaction of representatives of Kresy environment. However, Ukrainian who was murdered by Poles just on the eve of that day had killed his own brother, who demanded him to join the massacre, and killed his own wife, who was Pole. And while in the case of actions against Poles we have straight and unopposed references to their executors (Ukrainian nationalists), the spectator here was left without such landmarks.

The perceptual problem while watching the film is that even these segmentally truth facts, gathered in one place and shown as one person saw all of these events, create a single deformed picture of what happened in the years of World War II. All subjects selected by the director served a clearly defined goal - to secure exclusive role of the "victim" for "us" and to pass all responsibility for the tragedy to "them" (read - Ukrainians), ignoring the causal relationships. The film by Wojciech Smarzowski is completely inscribed into the discourse of "Kresy", which is characterized by only an apparent dialogue, which really is a monologue with the images of the past, in which "them" play the role of background artists or even "executors". These are "our Kresy", where others live, but the main interest, the most important is our history and the very memory of it must be restored.

The problem of the film is also in the fact that it creates a general atmosphere of hatred and enlivens the "bloodsuckers of the past", which both nations have just begun to dispose of. In fact, such cinema does not make the spectator think about the causes and the magnitude of the tragedy, appealing more to feelings than to the ratio. In the eyes of the average spectator, who is not aware of the historical intricacies, the film has probably strengthened the negative stereotype of Ukrainians and created an antiUkrainian atmosphere. After all, the main part of the film is aimed at the demonization of the Ukrainian underground; we see the images of torture, we hear pathetic texts about the murder for Ukraine, and so on. Ukrainians clearly look worse against the background of the Germans or the Soviets (despite all the repressions and sending to Siberia shown); the Soviet partisans just steal moonshine and salo, however, they admit that they "could become sheep, as well as khokhols".

One way or another, the film caused a considerable public reaction both in Poland and in Ukraine. We can mark at least two formal indicators of it. The first. In the first week after the release of the film, according to official information, it was seen by nearly 230 thousand of spectators. This is the best result among the historical films in recent years. For comparison, according to Boxoffice.pl, Miasto 44 Jana Komasy (2014) was seen by 191,900 ,

ISSN 1728-9343 (Print)

ISSN 2411-3093 (Online)
Kamienienaszaniec Roberta Glińskiego (2014) - by 105,558 spectators (Polacychcą ogladać filmyhistoryczne, 2016: URL; Shmid, 2017). In general, we can talk about at least 1.5 million people who saw it. The second. Polish War Drama, created by Wojciech Smarzowski, received 9 of the 14 nominations for the "Orły 2017" award, the Polish "Oscar" analogue. The film is featured in all major nominations: "Best Movie", "Best Director", "Best Scenario", "Best Music", and "Audience Award". This popularity of the film (as well as the enthusiastic responses of some authors) allowed analysts to express the assumption that the film will shape the image of a Ukrainian among the present generation of Poles.

The situation with the screening of this film outside of Poland in not less interesting. In Vilnius, the capital of Lithuania, Wojciech Smarzowski's film was demonstrated within the framework of the film festival "Kino Pavasaris". Here it is worth noting that due to the contraversery of the film, the session was preceded by a special discussion in which on the one hand participated the head of the Ukrainian the Institute of National Remembrance Volodymyr Viatrovych, and on the other hand prof., director of the The Institute of Political Studies of the Polish Academy of Science Grzegorz Motyka. The noticable conclusion was made by the well-known Lithuanian historian Alvydas Nikžentaitis, who argued that the film would make the Ukrainian-Polish discussions on the topic of Volyn for the next 20 years impossible (Wiatrowycz krytykował ... URL). In Latvia the screening of the film in the Riga cinema Splendid Palace on October 27, 2017 was initiated by private people. After interrogating in the security police, the organizers Ruslana Pankratova and Oleksandr Gaponenko sent letters addressed to Andrzej Duda, President of Poland, and the Polish Ministry of Foreign Affairs, and to Prime Minister Mateusz Morawiecki, with information about promoting the spread of Bandera ideology by the Latvian authorities and persecuting those who speak the truth. It is symptomatic that the corresponding letters were also sent to the Polish Embassy in Latvia and the Office of the Procurator-General of Poland from the Polish partnership "Polonez" and the "Association Against Nazism" (Tarasov, 2018).

The events of the Ukrainian-Polish conflict in the Ukrainian series by Volodimir Lis' novel, "Century of Jacob" (directed by Bata Nedich, screenwriter Andriy Kokotyukha) look different. In the history of Ukraine through the eyes of the Volhynian peasant Jacob, who was born at the time of the Russian Empire and became old at the time of independent Ukraine, the Volyn tragedy acts as an attack on the Ukrainian village where the hero lives by the Polish group. At that tragic moment, the noble Pole (main heroine), who protects the peasants in the face if her attacking fellowmen, comes to the rescue. As a result, "... But when people found who saved them, they surrounded Zosya and Jacob, kissed Zosya's hands, and some of them knelt before her as if she was the holy ...". Human values outweighed in this film. By the way, this film was presented in 2016 as well as "Volyn" by Wojciech Smarzowski.

Equally noticeable is the information that appeared recently about the intention of starting the new film. The Polish director Konrad Lentsky (author of the film named "Wyklęty") has started preparing the work named "Łuna", which will be devoted to the Ukrainian-Polish relations of 1943-1947, and will refer to the events in Volhynia, the Polish guerrilla activity in this region in the final part events in the Beskids of the postwar period. The artist himself defined his position as follows: "The film is a reminder of these people, because it seems to me that if,

SKHID No. 2 (160) March-April 2019 
during 20 years of so-called freedom, there was only one film created on this topic and this is, of course, very few. I think that the magnitude of the tragedy these people have faced with is so great that its implementation in one film, albeit prominent, is not enough" (Trojan, 2018).

On the other side, we should note the position of the well-known Polish director Jerzy Hoffman, who declared his refusal to shoot a film about Volhynian events. The refusal was motivated by the fact that every peasant war is cruel, and when people who survived from one side and the other are dead, when those who raised their children in mutual hatred die, relations between people would become normal.

The vision of the past can be promoted through cartoons successfully. The cartoon "Ludobójstwo" is not just an animation, its authors claims to the documentary, and the cartoon itself is a story about crimes against the Poles in the period after 1939 (from the Oswiecim camp to the Volyn massacre). Its creator Arkadiusz Olszewski found his audience on YouTube. The second cartoon is "Escape" by Yaroslav Konopka, produced as a classic puppet animation. As stated in the description, the film is full of stories of witnesses who "experienced their own death" in Volhynia.

The presentation of the problems of ethnic antagonisms is not something extraordinary on the stage. It is worth mentioning the performance of the Warsaw theater "At liberty" (directed by Ondrej Spižák) by the text of the play "Our Class" by Tadeusz Slobodzianek which refers to the tragic for the Poles and Jews events in the Jedwabne. Similarly, for example, the Ukrainian-Polish conflict appeared in Bydgoszcz in the "Wedding" by Stanislaw Wspyński (directed by Marcin Liber).

For the first time the topic of Volhynian events came to the theater, when the "Ballad of Volhynia" was presented at the Independence Museum in Warsaw by Tarnovskiy theater Nie Teraz in 2011. Director, screenwriter and stage designer Tomasz Antoni Żak used the novel of W łodzimierz Odojewski "Zasypiewszystko, zawieje" and eyewitness accounts in his theatrical adaptation. The statement can be divided into two parts. The first is the story of tragic deaths, torments through the stories of three women, who tell about the fate of their relatives and neighbors (one of the heroines is Ukrainian); the second is a metaphorical scene after a tragedy, when women try to wash away their memories of blood and resort to self-flagellation. It is noteworthy that the director, who was born in a family of people from Volyn, formulated as his task to affects as many his fellow-citizens as possible with the death of Polish, since "Motherland is the land and graves. The people, who lose their memory, lose their lives".

The play "Aporia'43 / Decalogue: Local World War" was one of the first attempts to speak about the Volhynian events of 1943 in the theatrical parlance (Dudko, 2012). At the same time, it was an attempt of common reassessment of the complicated historical past and attempts to develop at least a scenic dialogue between Ukrainian and Polish artists if not a common vision of the past. In this project the Polish side was presented by the Lublin director Lukas Wit-Michalowski (theatre "Scena Prapremier In vitro") in collaboration with the playwright Artur Pałyga. The Ukrainian side was placed in by the Kharkiv theater "Arabesque" (directed by Svitlana Oleshko). The Volyn tragedy was at the center exactly in Polish part. It starts a modern dialogue between Ukrainians and Poles, where they discuss peacefully routine things (food, women) until the subject of the conversation touches on history. Right here appears a gulf of misunderstanding between the two sides. The diptych is based on the personal story of a woman who experienced the Volyn tragedy. Her memories kept many naturalistic details of torture of Polish inhabitants by Ukrainians. This story is intertwined with the current situation, when the Polish side wants, despite all, to count its victims. The simple and unpretentious, at first glance, history of murder and hatred is complicated by the situation when there were many mixed Ukrainian-Polish families in the Volyn villages. The story of the atrocities of Ukrainians is finished with the scene, where in the afterlife an old Pole meets a Ukrainian girl who saved her at the cost of her own life. However, small stories of humanity are not able to overcome the gap that was left in history (the symbol of it was the forest of forks and scythes that were symbols and peace work on earth, and the struggle that took place on it at the same time). The Ukrainian part became the final part of the "Arabesques" triptych - the Chernobyl disaster "Chornobyl", the Holodomor "Letters from Kharkov" and "Decalogue" - about the most traumatic events of Ukrainian history (Dudko, 2012).

Another play by Teatr Polski w Bydgoszcz was named "Welding". The form of the performance was simple: there was the bench for spectators made of a strict rough tree and the same ambos for actors. Such furniture could be perceived as a church, a court or a school. At the ground of the performance were accounts of eyewitnesses collected in Ukraine and Poland, presented in the form of a film reportage translated into the theatrical parlance (Wlekły, 2015: 6-8). Despite the political relevance of the topic, the artists tried to remain neutral. As the authors said, their intention was to find the key to understanding the tragic past in the fragments of memories. We can see it in fragment with the analysis of the image of three dead children tied to the tree with the wire. Authors not only show that it actually belonged to the victims of the mother who killed her children in the prewar time, but also analyze the mechanism by means of which it became "evidence" in the Volyn cause (Pastuszewski, 2015).

\section{Discussion}

So, the description of the image of the Volhynian events in documentary and feature films, theatrical performances made by the author confirms the basic research hypothesis that they are an element of the forming the historical memory and a part of the politics of memory, the effectiveness of which is reflect in the results of sociological surveys.

Since the main task of cinematographers is to work with the spectators' emotions, it seems particularly important to show such ticklish events as the Volyn tragedy balanced and constructive, without reducing them to onesided black and white interpretation.

Speaking about practical results of the research, they can be useful for state institutions (when forming different plans and programs) as well as for educational institutions (during the work with youth concerning difficult pages from the past).

\section{Conclusion}

Conclusions of Łukasz Jasina, that Poles want to speak about their tragedy and their version does not seem close to what Ukrainians want to speak about, so, there is no approach in popular memory of both nations, sound entirely fair (Jasina, 2012: 716-717). Anyway, worth reminding is a thought of David Rieff, who argued that, briefly speaking, an attempt to discover the truth is solely the thing of his- 
torians. It is they who are able (sometimes, but not always) to find the truth about events that happened tens of years ago on the ground of archive materials and sources (Rieff, 2016). However, works of artists, texts of publicists, politicians and other public figures are only interpretation of historical knowledge. At the same time, the power of impact of cinema should be remembered. That, in fact, documentary and feature films, theatrical performances convey certain implicit political messages, form certain social norms, behavior patterns, and they are perceived by the spectator regardless of his or her preferences. Therefore, the functioning of such difficult topics of the past as the Volyn tragedy in cinema should meet the requirements of truthfulness, accuracy, diversity of thoughts.

\section{REFERENCES}

Dudko, Oksana (2012). Aporia'43. Dekaloh: lokalna svitova viyna. Retrieved from: http://www.historians.in.ua/index.php/en/ is toriya-i-pamyat-vazhki-pitannya/446-oksana-dudkoaporiia43dekaloh-lokalna-svotova-viina (Accessed 17 February 2019) (In Ukrainian).

Hud, Bogdan (2018). Z istoriyi etnosotsialnykh konfliktiv. Ukrayintsi y polyaky na Naddnipryanshchyni, Volyni y u Skhidniy Halychyni v XIX - pershiy polovyni XX st. Kharkiv: Acta, 482 p. (In Ukrainian).

Ilyushyn, Igor (2001). Protystoyannya UPA i AK (Armii Krayovoi) $v$ roky Druhoi svitovoi viyny na tli diyalnosti polskoho pidpillya $\checkmark$ Zakhidniy Ukraini. Kyiv: Institute of History of Ukraine of the National Academy of Sciences of Ukraine, 289 p. (In Ukrainian).

Jasina, Łukasz (2012). Unsuccessful reconciliation. Film, Wołyń and Chełmszczyzna. In: M. Kucherepa (comp.) Volyn i volynyany. Lutsk: 716-717 pp. (In Poland).

Kalishchuk, Oksana (2016). U tini Volyni? Istoriya vs pamyat. Lviv: I. Krypiakevych Instytut of Ukrainian of the National Academy of Sciences of Ukraine, 162 p. (In Ukrainian).

Lansberg, Alison (2004). Prosthetic memory. The Transformation of American Remembrance in the Age of Mass Culture. New York: Columbia University Press, 240 p. (In English)

Łukaszów [T.A. Olszański] (1989). Walki polsko-ukraińskie 1943-1947. Zeszyty Historyczne (Paryż) 1989, p. 90 (In Poland)

Marchenko, Serhij (2002). Historia Sacra chy Historia Profana? Aspekty vidobrazhennya istorychnoho materialu $v$ piznavalnomu kino. Retrieved from: http://www.ktm.ukma.edu.ua/2002/ 4/historia.htm (Accessed 17 February 2019) (In Ukrainian).

Mój przyjaciel wróg. Would you save your neighbor? Retrieved from: http://myfriendtheenemyfilm.com/polish_lang_page.html (Accessed 17 February 2019)

Motyka, Grzegorz (2016). Woł yń '43: ludobójcza czystka: fakty, analogie, polityka historyczna. Krakow: Wydawnyctwo Literackie, 288 p. (In Poland)

Pastuszewski, Stefan (2015). Swarka - recenzion. Akant: miesięcznik literacki, 11: 30-31 (In Poland)

Patryliak, Ivan (2014). Ukrayinsko-polskyy zbroynyy konflikt u roky Druhoyi svitovoyi viyny. Sproba syntetychnoho pohlyadu. Storinky istoriyi. Storinky istorii, 37: 148-159 (In Ukrainian).

Polacy chca oglądać filmy historyczne - "Wołyń" z rekordem otwarcia. Retrived from: http://telewizjarepublika.pl/polacy-chcaogladac-filmy-historyczne-wolyn-z-rekordem-otwacia,39165.html (Accessed 17 February 2019).

Rieff, David (2016). In Praise of Forgetting: Historical Memory and Its Ironies. New Haven: Yale University Press, 160 p. (In English)

Shmid, Ulrykh (2017). Lektsiyi z istoriyi u polskykh filmakh. Misto 44, Smolensk i Volyn yak vizualizovanyy dyskurs zhertvy. Retrieved from: http://www.historians.in.ua/index.php/en/istoriyai-pamyat-vazhki-pitannya/2245-ulrikh-shmid-lektsiji-istoriji-u- polskikh-filmakh-misto-44-smolensk-i-volin-yak-vizualizovanijdiskurs-zhertvi (Accessed 7 March 2019) (In Ukrainian).

Sowa, Andrzej Leon (1998). Polish-Ukrainian relations 19391947. Krakow, 342 p. (In English)

Strilchuk, Liudmyla (2018). The Ukrainian-Polish Confrontation in Volhyniain the Second World War: Historical Memory Transformations. Codrul Cosminului, $24 \mathrm{Nr}$ 1: 145-164. (In English)

Tarasov, Anatoliy (2018). Latviya protivitsya kritike zverstv Volynskoy rezni. Retrieved from: https://bb.lv/statja/politika/2018/ 02/15/latviya-protivitsya-kritike-zverstv-volynskoi-rezni (Accessed 7 March 2019) (In Russian).

Torzecki, Ryszard (1993). Pot acy and Ukrainians. The Ukrainian case during the Second World War in the Second Polish Republic. Warsaw: Wyd-wo Naukowe PWN, 349 p. (In Poland)

Trojan, Marek (2018). From Volhyn to the Bieszczady. The director of Wyklętego begins work on the new film - "Luna". Retrieved from: https://kresy.pl/wydarzenia/od-wolynia-pobieszczady-rezyser-wykletego-rozpoczyna-prace-nad-nowymfilmem-lunal (Accessed 17 February 2019).

Vyatrovich, Volodymyr (2011). Druha polsko-ukrayinska viyna. 1942 - 1947. Kyiv: Vyd. dim "Kyevo-Mohylyanska akademiya", 288 p. (In Ukrainian).

Wiatrowycz criticized the film "Wołyń" in Vilnius. Retrieved from: https://kresy.pl/wydarzenia/wiatrowycz-krytykowal-wwilnie-film-wolyn/ (Accessed 17 February 2019)

Wlekły, Mirosław and Szyngiera, Katarzyna (2015). "Swarka: rzeź wołyńska: 72 rocznica. Duży Format: czwartkowiec "Gazety Wyborczej", Lipiec 9: 6-8. (In Poland)

\section{LIST OF REFERENCE LINKS}

В'ятрович В. М. Друга польсько-українська війна. 1942 1947. Київ: Вид. дім "Києво-Могилянська академія", 2011. $288 \mathrm{c}$.

Гудь Б. 3 історії етносоціальних конфліктів. Українці й поляки на Наддніпрянщині, Волині й у Східній Галичині в XIX першій половині XX ст. / Авторизований переклад з польської Андрія Павлишина. Харків: Акта, 2018. 482 с.

Дудко О. Апорія'43 / Декалог: локальна світова війна. URL: http://www. historians.in.ua/index.php/en/istoriya-i-pamyatvazhki-pitannya/446-oksana-dudko-aporiia43dekaloh-lokalnasvotova-viina (дата звернення 17.02.2019).

Ільюшин І. Протистояння УПА і АК (Армії Крайової) в роки Другої світової війни на тлі діяльності польського підпілля в Західній Україні. Київ: Інститут історії України НАН України, 2001. 289 c.

Каліщук О. У тіні Волині? Історія vs пам'ять. Львів: Інститут українознавства ім. І. Крип'якевича НАНУ, 2016. 162 с.

Марченко C. Historia Sacra чи Historia Profana? Аспекти відображення історичного матеріалу в пізнавальному кіно. URL: http://www.ktm.ukma.edu.ua/2002/4/historia.htm (дата звернення 17.02.2019).

Патриляк І. Українсько-польський збройний конфлікт у роки Другої світової війни. Спроба синтетичного погляду. Сторінки історії. Київ, 2014. Вип. 37. С. 148-159.

Тарасов А. Латвия противится критике зверств Волынской резни. URL: https://bb.Iv/statja/politika/2018/02/15/latviyaprotivitsya-kritike-zverstv-volynskoi-rezni (дата звернення 07.03.2019).

Шмід У. Лекції з історії у польських фільмах. Місто 44, Смоленськ і Волинь як візуалізований дискурс жертви. URL: http://www.historians.in.ua/index.php/en/istoriya-i-pamyatvazhki-pitannya/2245-ulrikh-shmid-lektsiji-istoriji-u-polskikhfilmakh-misto-44-smolensk-i-volin-yak-vizualizovanij-diskurszhertvi (дата звернення 07.03.2019).

Jasina Ł. Nieudane pojednanie. Film, Wołyń i Chełmszczyzna. 
Волинь і волиняни: зб. наук. пр. за матеріалами I Міжнар. наук. конф., присв. подіям Другої світової війни на території Волині / упоряд. М. Кучерепа. Луцьк, 2012. С. 716-717.

Lansberg A. Prosthetic memory. The Transformation of American Remembrance in the Age of Mass Culture. New York: Columbia University Press, 2004. 240 p.

Łukaszów J. [T.A. Olszanński], Walki polsko-ukraińskie 19431947. Zeszyty Historyczne (Paryż) 1989, z. 90.

Mój przyjaciel wróg. Would you save your neighbor? URL: http://myfriendtheenemyfilm.com/polish_lang_page.html (дата звернення 17.02.2019).

Motyka G. Wołyń '43: ludobójcza czystka: fakty, analogie, polityka historyczna. Kraków: Wydawnictwo Literackie, 2016. $288 \mathrm{~s}$.

Pastuszewski S.Swarka - recenzja. Akant: miesięcznik literacki, 2015. № 11. S. 30-31.

Polacy chcą oglądać filmy historyczne - "Wołyń" z rekordem otwarcia. URL: http://telewizjarepublika.pl/polacy-chca-ogladacfilmy-historyczne-wolyn-z-rekordem-otwacia,39165.html (дата звернення 17.02.2019).
Rieff D. In Praise of Forgetting: Historical Memory and Its Ironies. New Haven: Yale University Press, 2016. 160 p.

Sowa A. L. Stosunki polsko-ukraińskie 1939-1947. Kraków: Towarzysrwo przyjaciół Nauk, 1998. 342 p.

Strilchuk L. The Ukrainian-Polish Confrontation in Volhynia in the Second World War: Historical Memory Transformations. Codrul Cosminului, 2018, $24 \mathrm{Nr}$ 1, P. 145-164.

Torzecki R. Połacy i Ukraińcy. Sprawa ukraińska w czasie II wojny światowej na terenie II Rzeczypospolitej. Warszawa: Wydwo Naukowe PWN, 1993. 349 s.

Trojan M. Od Wołyniapo Bieszczady. Reżyser "Wyklętego" rozpoczy napracenadnowym filmem - "Łuna". URL: https://kresy.pl/ wydarzenia/od-wolynia-po-bieszczady-rezyser-wykletegorozpoczyna-prace-nad-nowym-filmem-luna/ (дата звернення 17.02.2019).

Wiatrowycz krytykował w Wilnie film "Wołyń". URL: https:// kresy.pl/wydarzenia/wiatrowycz-krytykowal-w-wilnie-filmwolyn/ (дата звернення 17.02.2019).

Wlekły M., Szyngiera K. Swarka: rzeź wołyńska: 72 rocznica. Duży Format: czwartkowiec "Gazety Wyborczej", 2015, 9 Lipca, S. 6-8.

\section{Каліщук Оксана,}

Східноєвропейський національний університет імені Лесі Украйнки (м. Луиьк, Украӥна)

e-mail: kalis@ukr.net, ORCID0000-0003-1272-7920

\section{ВОЛИНСЬКА ТРАГЕДІЯ У КІНОЙ ТЕАТРІ}

Кіно справедливо уважають потужним соціокомунікаційним каналом інформаційного простору. Його значущість підсилена у випадку звернення до дражливих тем. У статті запропоновано огляд зразків кіно- та театрального мистецтва, присвячених українсько-польському протистоянню у роки Другої світової війни на західних землях України. Закцентовано увагу не лише на сюжетному розмаїтті стрічок, а й на філософській, герменевтичній, психоаналітичній можливостях й потребі їх ґрунтовного вивчення. Так, зокрема, хроніко-документальним та науково-популярним фільмам став властивий акцент на індивідуалізацію волинських подій через особу свідків, тих, хто її пережив. Особливістю документального кіно про Волинь'43 є неможливість зробити його більш естетичним та відстороненим. Основним завданням і кінематографу, і театру на сучасному етапі слід уважати здатність викликати емоційне співпереживання. На сьогодні кіно- та театральні твори є елементом національної самоідентифікації та формування національної пам'яті. Документальні, і особливо художні фільми можуть відновлювати та закріплювати старі стереотипи і творити нові міфи. Через засоби сучасного мистецтва досвід більш ніж семидесятирічної давнини стає досвідом сучасників. Зроблено висновок, що і документальне, і художнє кіно, і театральні вистави є одним із шляхів міжнаціонального діалогу. Яскравим увиразненням надважливості є бурхливі дискусії, які викликають в українському та польському суспільствах такі художні фільми, як "Волинь" Войцеха Смажовського. Водночас, слід розуміти, що важливо говорити про ті теми, які є болючими для спільноти.

Ключові слова: Волинська трагедія; театр; документальний фрільм; художній фрільм.

(C) Kalishchuk Oksana

Надійшла до редакції: 15.03.2019

Прийнята до друку: 12.04.2019 